Genome Insight

Plant Genetics

\title{
Characterization of the complete plastid genome of Butia eriospatha (Arecaceae)
}

Jeison Willy de Souza Magnabosco ${ }^{1}$, Hugo Pacheco de Freitas Fraga ${ }^{1}$, Raquel Santos da Silva ${ }^{1}$, Marcelo Rogalski $^{2}$, Emanuel Maltempi de Souza ${ }^{3}$, Miguel Pedro Guerra ${ }^{4,5}$ iD and Leila do Nascimento Vieira ${ }^{1}$ iD

${ }^{1}$ Universidade Federal do Paraná, Programa de Pós-graduação em Botânica, Curitiba, Paraná, Brazil.

${ }^{2}$ Universidade Federal de Viçosa, Programa de Pós-graduação em Fisiologia Vegetal, Viçosa, MG, Brazil.

${ }^{3}$ Universidade Federal do Paraná, Programa de Pós-graduação em Bioquímica e Biologia Molecular, Curitiba, PR, Brazil.

${ }^{4}$ Universidade Federal de Santa Catarina, Programa de Pós-graduação em Recursos Genéticos Vegetais, Florianópolis, SC, Brazil.

${ }^{5}$ Universidade Federal de Santa Catarina, Programa de Pós-Graduação em Ecossistemas Agrícolas e Naturais, Curitibanos, SC, Brazil.

\begin{abstract}
Butia eriospatha is an endemic palm species from the Atlantic Rainforest in Brazil, a biodiversity hotspot. This species is currently listed in the IUCN red list as vulnerable and lacks specific plastid markers for population genetics studies. In addition, the evolutionary relationship within the genus Butia is not yet well resolved. Here, we sequenced and characterized the complete plastid genome (plastome) sequence of $B$. eriospatha. The complete plastome sequence is $154,048 \mathrm{bp}$ in length, with the typical quadripartite structure. This plastome length and genes content is consistent with other six species from tribe Cocoseae. However, the Inverted Repeat (IR) borders show some variation among the analyzed species from this tribe. Species from the Bactridinae (Astrocaryum and Acrocomia) and Elaeidinae (Elaeis) subtribes present the rps 19 gene completely duplicated in the IR region. In contrast, all plastomes sequenced from the subtribe Attaleinae (Butia, Cocos, Syagrus) present one complete CDS of rps19and one partial copy of rps19. The difference in the IR/LSC junctions between Attaleinae and the sister clades Bactridinae + Elaeidinae might be considered an evolutionary signal and the plastome sequence of $B$. eriopatha may be used in future studies of population genetics and phylogeny.
\end{abstract}

Keywords: Palm, atlantic rainforest, plastome, molecular evolution.

Received: February 06, 2020; Accepted: July 10, 2020.

The family Arecaceae, comprises approximately 188 genera and 2,585 species, distributed throughout tropical and subtropical climate of the world, but it is most diverse in tropical forest habitats, being present from Americas to Asia-Pacific region (Palmweb).

Butia (Becc.) Becc. is a genus of the family Arecaceae, indigenous from South America. This genus includes 18 species (WFO, 2019), among them Butia eriospatha (Mart. ex Drude) Becc.. This species is endemic to southern Brazil and occurs in the Atlantic Rainforest phytogeographic domain: mainly in high altitude grassland, grassland, palm grove (Heiden et al., 2020). Butia eriospatha is easily distinguished by its solitary stem with 4-5 meters in hight, globose fruit, spathe ferruginous-pubescent on outer surface, and pistillate flowers with 3-7 mm (Deble et al., 2011; Heiden et al.,

Send correspondence to Leila do Nascimento Vieira. Universidade Federal do Paraná, Programa de Pós-graduação em Botânica, Rua Coronel Francisco H. dos Santos s/n, 81531-980 Curitiba, PR, Brazil. E-mail: leilavieira@ufpr.br.
2020). Among palms, B. eriospatha has a high economic importance, being used for ornamentals projects, and with edible fruits. Currently, the fruits are consumed fresh or in pulp, alcoholic drinks, jams, jellies or ice cream (Hoffmann et al., 2014).

Species of the genus Butia show the same chromosome number $(2 \mathrm{n}=2 \mathrm{x}=32)$ (Correa et al., 2019) and the genus is well supported as monophyletic (Meerow et al., 2015). However, within Butia, few molecular markers were used in phylogenetic studies. The most recent study on Butia phylogeny used only one plastid marker $(\operatorname{trnH}-p s b A)$ and two nuclear markers (ITS and WRKY19) and failed to resolve the evolutionary relationship between Butia species (Pereira, 2019).

Plastome sequences are frequently used to understand evolutionary events and efficiently resolve phylogenetic relationships (Lopes et al., 2018, 2019). Typically, the plastome is represented as a single circular molecule composed by two inverted regions (IR), a large single copy (LSC) and a 
small single copy (SSC), with 120 to 130 genes, encoding ribosomal RNA (rRNA), transfer RNA (tRNA) and peptides. The plastome size varies from $107 \mathrm{~kb}$ to $218 \mathrm{~kb}$, depending on each species (Daniell et al., 2016; Menezes et al., 2018).

Here we report the complete plastome of $B$. eriospatha and describe its structure and gene composition. For this, $B$. eriospatha leaves were collected from a single individual at the Federal University of Santa Catarina - Brazil. DNA isolation with plastid DNA-enrichment was performed according to Vieira et al. (2014). The DNA was quantified using Qubit $^{\circledR}$ fluorometer (Invitrogen, Carlsbad, CA) and $1 \mathrm{ng}$ of DNA was used for preparing sequencing libraries with Nextera XT DNA Sample Prep Kit (Illumina Inc., San Diego, CA). Libraries were sequenced on Illumina MiSeq (Illumina Inc.). The obtained paired-end reads $(2 \times 300 \mathrm{bp})$ were used for de novo assembly in CLC Genomics Workbench 8.0v.
The plastome annotation was performed using DOGMA software (Wyman et al., 2004) followed by manual curation using Geneious (Kearse et al., 2012). The graphical map of plastomes was generated by OrganellarGenomeDRAW (OGDRAW) (Greiner et al., 2019). The complete nucleotide sequence of $B$. eriospatha (MN329806) plastome was deposited in the GenBank database. The junction site of plastomes (LSC/IR, IR/SSC) from the tribe Cocoseae (Arecaceae: Arecoideae) were visualized and compared using IRScope (Amiryousefi et al., 2018).

Butia eriospatha plastome is a circular molecule with $154,048 \mathrm{bp}$ in length and the typical quadripartite structure, including a large single copy with $83,805 \mathrm{bp}$, two inverted repeat regions $(26,437 \mathrm{bp})$ and a small single copy with 17,369 bp (Figure 1). This plastome assembly was realized with 457,423 plastid reads (all trimmed with 0.05 quality

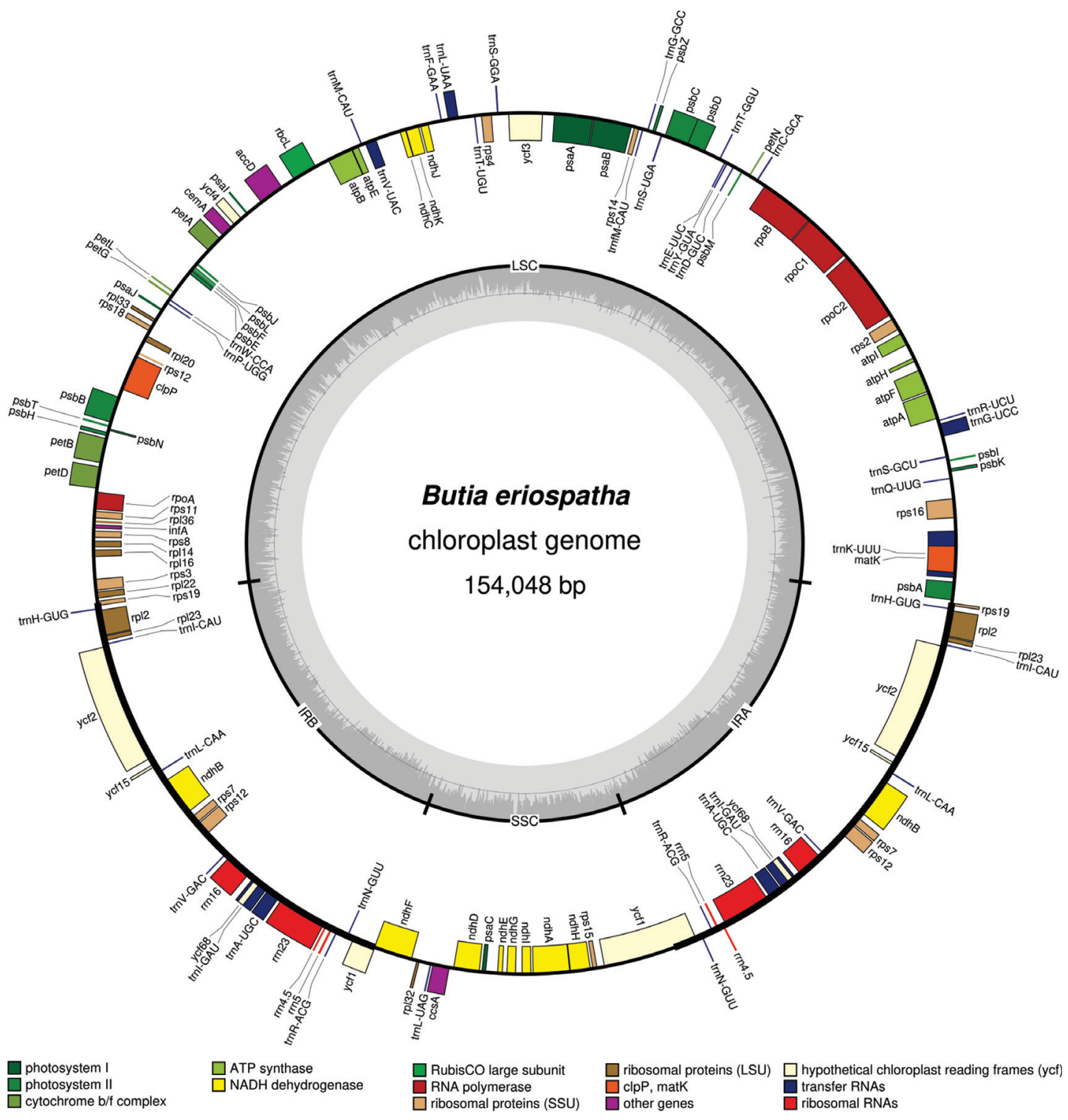

Figure 1 - Graphical map of Butia eriospatha plastid genome. Genes shown on the outside of the circle are transcribed clockwise; genes on the inside are transcribed counterclockwise. Genes were grouped and represented by different colors according their function group. The GC content is represented by the dashed darker grey area in the inner circle, the lighter grey area represents AT content. 
scores in CLC Genomics Workbench), which resulted in approximately 820x genome coverage depth. The minimum genome coverage was $206 x$, which shows the high coverage sequencing of this plastome.

This plastome encodes 113 unique genes, being 79 protein-code genes, 30 tRNA genes and four rRNA genes (Table 1), the same number as the other Cocoseae species (Lopes et al., 2018, 2019). The 20 duplicated genes in the IRs are: eight protein-coding genes (among them, the $y c f 1$ and rps 19 are partially duplicated), eight tRNA genes, and all four rRNA genes. Among the 113 genes, 16 contain one intron (10 protein-codes genes, and six rRNA), and three contain two introns (clpP, ycf3 and rps 12) (Table 1).

The size of the plastome of $B$. eriospatha was compared with others plastomes from species in the same tribe: Cocoseae (Table 2). They have similar length and structure, varying in the LSC from 83,805 bp to $85,192 \mathrm{bp}$, the SSC from $17,369 \mathrm{bp}$ to $17,639 \mathrm{bp}$ and the IRs from $26,437 \mathrm{bp}$ to $27,092 \mathrm{bp}$. This variation can be better visualized in the IRs borders (Figure 2). Species from the subtribes Bactridinae

Table 1 - List of genes identified in the plastome of Butia eriospatha.

\begin{tabular}{|c|c|}
\hline Group of genes & Name of gene \\
\hline \multicolumn{2}{|l|}{ Gene expression machinery } \\
\hline Ribossomal RNA genes & $\operatorname{rrn} 4.5^{a} ; \operatorname{rrn} 5^{a} ; \operatorname{rrn} 16^{a} ; \operatorname{rrn} 23^{a}$ \\
\hline Transfer RNA genes & $\begin{array}{l}\operatorname{trn} A-U G C^{a b} ; \operatorname{trn} C-G C A ; \operatorname{trn} D-G U C ; \operatorname{trn} E-U U C ; \operatorname{trn} F-G A A ; \operatorname{trn} f M-C A U ; \operatorname{trn} G-U C C^{b} ; \operatorname{trn} G-G C C ; \\
\operatorname{trn} H-G U G^{a} ; \operatorname{trn} I-C A U^{a} ; \operatorname{trn} I-G A U^{a b} ; \operatorname{trn} K-U U U^{b} ; \operatorname{trn} L-C A A^{a} ; \operatorname{trn} L-U A A^{b} ; \operatorname{trn} L-U A G ; \operatorname{trn} M-C A U ; \operatorname{trn} N-G U U^{a} \text {; } \\
\operatorname{trn} P-U G G ; \operatorname{trn} Q-U U G ; \operatorname{trn} R-A C G^{a} ; \operatorname{trn} R-U C U ; \operatorname{trn} S-G C U ; \operatorname{trn} S-U G A ; \operatorname{trn} S-G G A ; \operatorname{trn} T-U G U ; \operatorname{trn} T-G G U ; \\
\operatorname{trn} V-G A C^{a} ; \operatorname{trn} V-U A C^{b} ; \operatorname{trn} W-C C A ; \operatorname{trn} Y-G U A\end{array}$ \\
\hline Small subunit of Ribossome & rps2; rps3; rps4; rps $7^{a} ; r p s 8 ; \operatorname{rps} 11 ; \operatorname{rps} 12^{a b} ; \operatorname{rps} 14 ; \operatorname{rps} 15 ; \operatorname{rps} 16^{b} ; \operatorname{rps} 18 ; r p s 19^{a}$ \\
\hline Large subunit of Ribossome & $r p l 2^{a b} ;$ rpl4; rpl16 $;$ rpl20; rpl22; rpl23 ; rpl32; rpl33; rpl36 \\
\hline DNA-dependent RNA Polymerase & rроA; rроB; rpoCl $1^{b}$ rросC2 \\
\hline Translational initiation factor & $\operatorname{infA}$ \\
\hline Maturase & matK \\
\hline \multicolumn{2}{|l|}{ Genes for photosynthesis } \\
\hline Subunits of photosystem I (PSI) & psaA; psaB; psaC; psaI; psaJ; ycf3 $3^{b} ; y c f 4$ \\
\hline Subunits of photosystem II (PSII) & 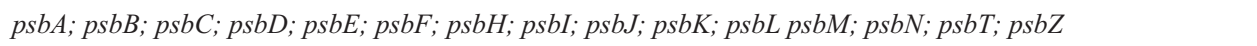 \\
\hline Subunits of cytochrome b6f & petA; petB $B^{b} ; \operatorname{pet} D^{b} ; \operatorname{pet} G ; \operatorname{pet} L ; \operatorname{pet} N$ \\
\hline Subunits of ATP synthase & atpA; atpB; atpE; atpF $F^{b}$ atpH; atpI \\
\hline Subunits of NADH dehydrogenase & $n d h A^{b} ; n d h B^{a b} ; n d h C ; n d h D ; n d h E ; n d h F ; n d h G ; n d h H ; n d h I ; n d h J ; n d h K$ \\
\hline Large subunit of Rubisco & $r b c L$ \\
\hline \multicolumn{2}{|l|}{ Other functions } \\
\hline Envelope membrane protein & $\operatorname{cem} A$ \\
\hline Subunit of acetyl-CoA carboxylase & $a c c D$ \\
\hline C-type cytochrome synthesis & $\operatorname{ccs} A$ \\
\hline Subunit of protease Clp & $\operatorname{clp} P^{b}$ \\
\hline Component of TIC complex & $y c f 1$ \\
\hline Unknown function & $y c f 2^{a}$ \\
\hline
\end{tabular}

${ }^{\mathrm{a}}$ Duplicated genes; ${ }^{\mathrm{b}}$ Genes containing introns

Table 2 - General features of plastid genomes within the tribe Cocoseae.

\begin{tabular}{lllllll}
\hline Subtribe & Species & Total $(\mathrm{bp})$ & LSC (bp) & IR (bp) & SSC (bp) & Accession number \\
\hline Attaleinae & Butia eriospatha & 154,048 & 83,805 & 26,437 & 17,369 & MN_329806 \\
& Syagrus coronata & 155,053 & 84,535 & 26,522 & 17,474 & NC_029241 \\
& Cocos nucifera & 154,731 & 84,230 & 26,555 & 17,391 & NC_022417 \\
Elaeidinae & Elaeis guineensis & 156,973 & 85,192 & 27,071 & 17,639 & NC_017602 \\
Bactridinae & Astrocaryum & 156,804 & 85,037 & 27,081 & 17,605 & MH_537788 \\
& aculeatum & & & & \\
& Astrocaryum & 156,801 & 85,017 & 27,081 & & MH_537787 \\
& murumuru & & & & \\
& Acrocomia aculeata & 156,500 & 84,936 & 27,092 & & NC_037084 \\
\hline
\end{tabular}




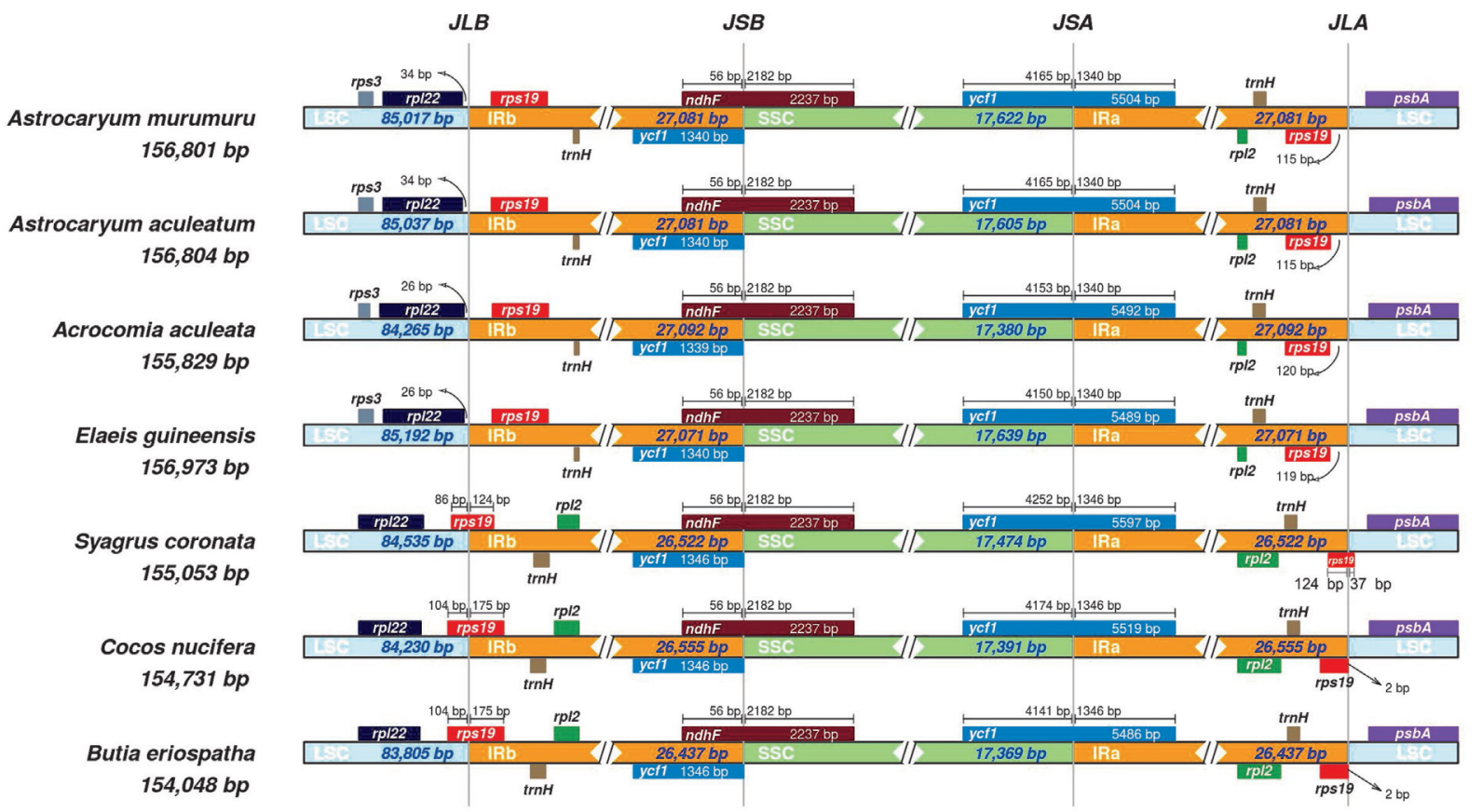

Figure 2 - Comparison of plastid genome LSC, IR, and SSC junction positions within the tribe Cocoseae (Arecaceae: Arecoideae). Genes shown below are transcribed counterclockwise and those shown above the lines are transcribed clockwise.

(Acrocomia and Astrocaryum) and Elaeidinae (Elaeis) present the rps 19 gene completely duplicated in the IR region. In contrast, all plastomes sequenced from subtribe Attaleinae (Butia, Cocos, Syagrus) present one complete CDS of rps19 and one partial copy of rps 19 , thus presenting only one functional copy of the gene (Figure 2). The intergenic spacers (IGS) between rpl22-rps 19 genes and rps 19-psbA genes, located in the LSC/IR $\mathrm{R}_{\mathrm{B}}$ and $\mathrm{IR}_{\mathrm{A}} / \mathrm{LSC}$ junctions, respectively, show variations in size within Cocoseae species (Figure 2). The $\mathrm{SSC} / \mathrm{IR}_{\mathrm{A}}$ junction varies mainly in the length of the $y c f 1$ gene portion contained within the SSC. The $n d h F$ gene is identical in length among all species studied and part of it is located within the $\mathrm{IR}_{\mathrm{B}}$, overlapping in part the $y c f 1$ gene (56 bp). The differences in the IR/LSC junctions between Attaleinae and the sister clades Bactridinae + Elaeidinae migth be considered an evolutionary signal and the plastome sequence of B. eriospatha may be used in future studies of population genetics and for phylogenetic studies.

\section{Acknowledgments}

This work was supported by Coordenação de Aperfeiçoamento de Pessoal de Nível Superior (CAPES), Conselho Nacional de Desenvolvimento Científico e Tecnológico (CNPq), and Fundação de Amparo à Pesquisa e Inovação do Estado de Santa Catarina (FAPESC 14848/2011-2, 3770/2012, and 2780/2012-4). The authors thank to the Brazilian Program of National Institutes of Science and Technology-INCT/Brazilian Research Council-CNPq/MCT.

\section{Conflict of Interest}

The authors declare that they do not have any conflict of interest.

\section{Author Contributions}

LNV, MPG, EMS, MR, and HPFF conceptualized the experiment; JWSM, LNV, HPFF and RSS performed the experiments and data analysis; EMS, MR, and MPG provided the reagents and materials; JWSM, LNV, and HPFF wrote the manuscript. All authors revised the final version of the manuscript.

\section{References}

Amiryousefi A, Hyvönen J and Poczai P (2018) IRscope: An online program to visualize the junction sites of chloroplast genomes. Bioinformatics 34:3030-3031.

Correa LB, Barbieri RL, Rossato M, Büttow MV and Heiden G (2009) Karyological characterization of Butia (Arecaceae) palm trees. Rev Bras Frutic 31:1111-1116.

Daniell H, Lin CS, Yu M and Chang WJ (2016) Chloroplast genomes: Diversity, evolution, and applications in genetic engineering. Genome Biol 17:1-29.

Deble LP, Marchiori JNC, Alves FS and Oliveira-Deble AS (2011) Survey on Butia (Becc.) Becc. (Arecaceae) from Rio Grande do Sul state (Brazil). Balduinia 30:3-24.

Greiner S, Lehwark P and Bock R (2019) OrganellarGenomeDRAW (OGDRAW) version 1.3.1: Expanded toolkit for the graphical visualization of organellar genomes. Nucleic Acids Res 47:59-64

Hoffmann JF, Barbieri RL, Rombaldi CV and Chaves FC (2014) Butia spp. (Arecaceae): An overview. Sci Hortic 179:122-131. 
Kearse M, Moir R, Wilson A, Stones-Havas S, Cheung M, Sturrock S, Buxton S, Cooper A, Markowitz S, Duran C, Thierer T et al. (2012) Geneious Basic: an integrated and extendable desktop software platform for the organization and analysis of sequence data. Bioinformatics 28:1647-1649.

Lopes AS, Pacheco TG, Silva ON, Cruz LM, Balsanelli E, Souza EM, Pedrosa FO and Rogalski M (2019) The plastomes of Astrocaryum aculeatum G. Mey. and A. murumuru Mart. show a flip-flop recombination between two short inverted repeats. Planta 250:1229-1246.

Lopes AS, Pacheco TG, Nimz T, Vieira LN, Guerra MP, Nodari RO, Souza EM, Pedrosa FO and Rogalski M (2018) The complete plastome of macaw palm [Acrocomia aculeata (Jacq.) Lodd. ex Mart.] and extensive molecular analyses of the evolution of plastid genes in Arecaceae. Planta 247:1011-1030.

Menezes APA, Resende-Moreira LC, Buzatti RSO, Nazareno AG, Carlsen M, Lobo FP, Kalapothakis P and Lovato MB (2018) Chloroplast genomes of Byrsonima species (Malpighiaceae): Comparative analysis and screening of high divergence sequences. Sci Rep 8:1-12.

Meerow AW, Noblick L, Salas-Leiva DE, Sanchez V, Francisco-Ortega J, Jestrow B and Nakamura K (2015) Phylogeny and historical biogeography of the cocosoid palms (Arecaceae, Arecoideae, Cocoseae) inferred from sequences of six WRKY gene family loci. Cladistics 31:509-534.
Pereira PEE (2019) Filogenia de Butia (Arecaceae): um gênero de palmeiras sul-americano. Thesis, Universidade Federal de Pelotas, $62 \mathrm{p}$.

Vieira LN, Faoro H, Fraga HPF, Rogalski M, Souza EM, Pedrosa FO, Nodari RO and Guerra MP (2014) An improved protocol for intact chloroplasts and cpDNA isolation in conifers. PLoS One 9:e84792.

Wyman SK, Jansen RK and Boore JL (2004) Automatic annotation of organellar genomes with DOGMA. Bioinformatics 20:3252-3255.

\section{Internet Resources}

Heiden G, Ellert-Pereira PE, Eslabão MP (2020) Butia in Flora do Brasil 2020 under construction, http://floradobrasil.jbrj.gov.br/reflora/floradobrasil/FB26574 (accessed June 2020)

Palmweb - Palms of the world online, http://www.palmweb.org/node/2 (accessed December 2019).

WFO (2019) Butia (Becc.) Becc., http://www.worldfloraonline.org/taxon/wfo-4000005828 (accessed December 2019).

Associate Editor: Marcela Uliano da Silva

License information: This is an open-access article distributed under the terms of the Creative Commons Attribution License (type CC-BY), which permits unrestricted use, distribution and reproduction in any medium, provided the original article is properly cited. 